\title{
Craniometrical characteristics and dental anomalies in wolves Canis lupus from Latvia
}

\author{
Žanete ANDERSONE and Jānis OZOLIN̦Š
}

\begin{abstract}
Andersone Ž. and Ozolinš J. 2000. Craniometrical characteristics and dental anomalies in wolves Canis lupus from Latvia. Acta Theriologica 45: 549-558.

A total of 187 skulls ( 115 adult males and 72 adult females) of the wolf Canis lupus Linnaeus, 1758 hunted in Latvia between 1975-1999 were measured, using 19 craniometrical parameters. General cranial characteristics were similar to those described from the wolf populations of Belarus and Poland (the difference was not statistically significant). Sexual dimorphism in skull size was determined. Most of the skull parameters from north and east Latvia appeared to be slightly larger than those from the Kurland Peninsula, being isolated by large cities, rivers and deforested lands. Also, anomalies in tooth formula were described. Deviations from the normal tooth pattern were found in $9.5 \%$ skulls. Congenital oligodonty and polydonty was found in $7.9 \%$ skulls. Polydonty was observed in $71.4 \%$ cases of tooth anomalies. Tooth anomalies were more common in males than in females.

Kemeri National Park, "Meža māja", Kemeri - Jūrmala, LV-2012, Latvia, e-mail: kemeri@vdc.lv (ŻA); State Forest Service, 13. Janvāra Str. 15, Riga, LV-1932, Latvia (JO)

Key words: Canis lupus, craniometry, dental anomalies, Latvia
\end{abstract}

\section{Introduction}

In Latvia, unlike many other European countries, the wolf Canis lupus Linnaeus, 1758 is still a very common large carnivore. According to the official inventory data, the population totals about 700 animals, with the highest density in the western and eastern parts of the country. Although double counting cannot be excluded and the actual number may be much lower, the population size certainly reaches several hundred animals. It is traditionally regarded by the public, especially by hunters and farmers, as a pest and is severely persecuted all year round. Despite its wide distribution, abundance and a remarkable yearly hunting bag exceeding 300 individuals since 1995, morphology of the Latvian wolf population has not been studied before. Only some body measurements of the Latvian wolves are represented in the national literature (Kalniņš 1943, Tauriņš 1982) while in the neighbouring countries numerous craniometrical studies on the species have been carried out (Novikov 1956, Geptner et al. 1967, Bibikov 1985, Okarma and Buchalczyk 1993). 
The aim of this study was to give a basic craniometrical description of the wolf population in Latvia, to check the extent of sexual dimorphism of skull characteristics, and to compare craniometry of the Latvian wolves with those in the neighbouring territories.

\section{Material and methods}

Skulls of wolves hunted in Latvia in 1975-1999 were measured. The samples represented all the territory of Latvia $\left(64600 \mathrm{~km}^{2}\right.$ ), although most of the skulls originated from the eastern and western parts of the country, the regions of the highest wolf density. The River Daugava was chosen as a borderline between the Kurland Peninsula subpopulation (to the west from the river) and the northeastern subpopulation (from the region bordering with Estonia and Russia).

In total, 187 wolf skulls (115 males, 72 females) were measured. Thirty-two males and 21 female originated from the Kurland Peninsula. All the skulls studied were from hunters' private collections. In Latvia, wolf skulls are regarded as a valuable trophy. Male skulls predominate in the collections, since they are bigger and more impressive for exhibition than female skulls, which are often neglected. Only skulls of adult animals were measured since they present species specific characteristics. Sample size $(n)$ differed for individual parameters as not all the measurements were available for every skull due to their different condition.

The following 18 parameters (Fig. 1) were measured according to Novikov (1956) as well as taking into account Okarma and Buchalczyk (1993), Ansorge (1994), Ansorge and Meinig (1996):

$\mathrm{CbL}$ - condylobasal length (aboral border of the occipital condyles - Prosthion),

ToL - total length (Prosthion - sagittal crest),

$\mathrm{BaL}$ - basal length (from posterior edge of alveolus of $\mathrm{I}^{1}$ to Foramen supramastoideum),

FaL - facial length (Frontal midpoint - Prosthion),

$\mathrm{NeL}$ - upper neurocranium length (Frontal midpoint - Opisthion),

$\mathrm{NaL}$ - nasal length (length of joint between Nasale),

$\mathrm{MNaL}$ - maximum nasal length (from anterior edge of Nasale to its posterior edge),

$\mathrm{PaL}$ - palate length (from posterior edge of alveolus of $\mathrm{I}^{1}$ to anterior edge of Incisura palatina),

IPaL - length of incisura palatina (from its anterior edge to the posterior edge of Hamulus pterigoideus),

$\mathrm{C}^{1} \mathrm{~B}$ - breadth of alveolus of the upper canine $\mathrm{C}^{1}$ (measurement taken between exterior edges of canines),

ZyB - zygomatic breadth (Zygion - Zygion),

EntB - minimum breadth between the orbits (Entorbitale - Entorbitale),

LB - minimum breadth of skull (minimum aboral breadth of the supraorbital processes),

MB - maximum mastoid breadth (Othion - Othion),

SH - skull height,

MdL - total length of mandible (Infradentale - Condyle process),

TRL' - length of upper tooth row (from anterior edge of $\mathrm{P}^{1}$ to posterior edge of alveola of $\mathrm{M}^{2}$ ),

$\mathrm{C}_{1} \mathrm{Br}$ - breadth between interior edges of alveoli of the lower canine $\mathrm{C}_{1}$.

Measurements were taken with a caliper $(30 \mathrm{~cm})$ to an accuracy of $1 \mathrm{~mm}$. Cranial characteristics underwent statistical analysis; the significance level was checked by the Student's $t$-test (Liepa 1974, Sokal and Rohlf 1981). For each parameter, standard deviation (SD) and coefficient of variation (CV) were calculated. Also, the Storer's index of sexual dimorphism was calculated (Okarma and Buchalczyk 1993). In addition, skull mass (SM) was measured. The skulls were weighed only when completely dry using an electronic balance (SC-3000) to $1 \mathrm{~g}$ preciseness.

Tooth formula was checked in all the skulls investigated in order to reveal possible deviations. We checked if the tooth formula of the skulls was in accordance with the normal tooth pattern of the wolf: I 3/3 C 1/1 P 4/4 M 2/3 (Görner and Hacketal 1987). Presence or absence of teeth was assessed externally by checking alveoli. 


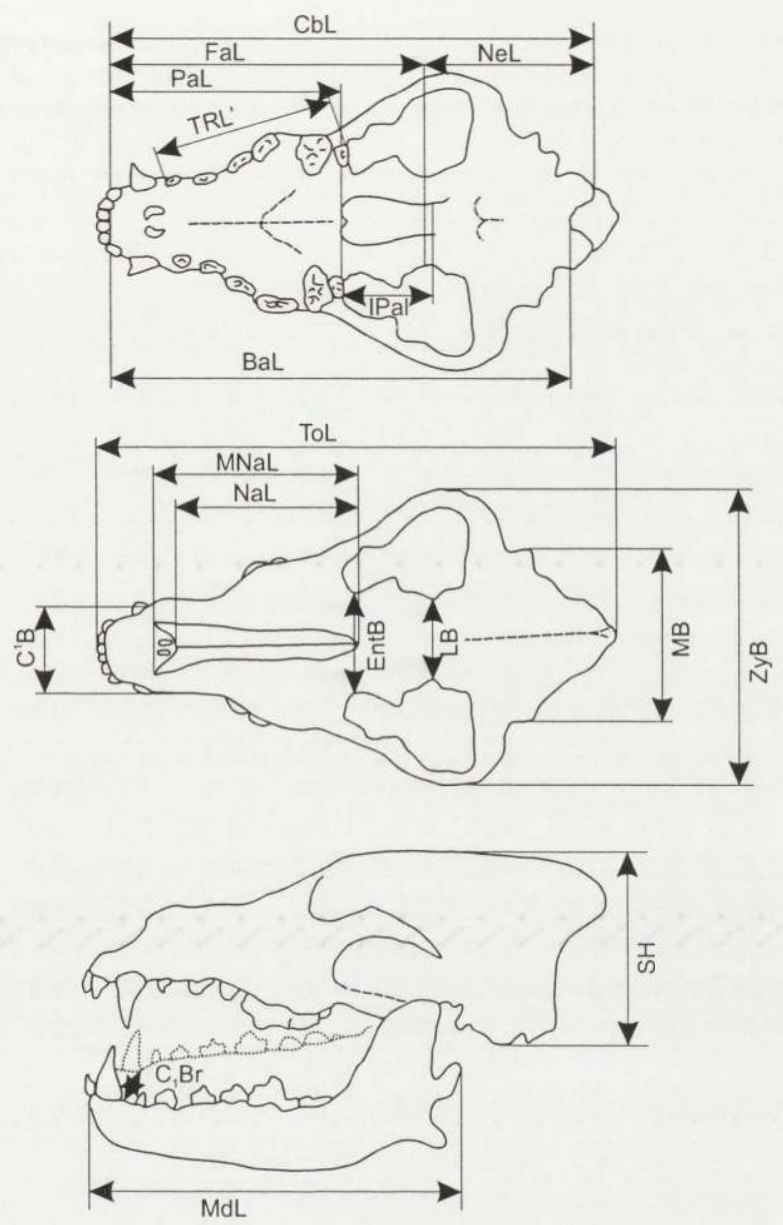

Fig. 1. Cranial parameters measured in wolf skulls. Explanations for each parameter are given in the text.

\section{Results}

Condylobasal length (CbL) of the wolf skulls measured varied from 20.0 to 25.9 $\mathrm{cm}$ (males: from 20.8 to $25.9 \mathrm{~cm}$, females: from 20.0 to $24.4 \mathrm{~cm}$ ). Zygomatic breadth (ZyB) ranged from 11.8 to $16.1 \mathrm{~cm}$ (males: $11.8-16.1 \mathrm{~cm}$, females: $11.9-14.7 \mathrm{~cm}$ ). All the craniometrical characteristics measured are shown in Table 1.

Male skulls were larger than those of females. The difference was statistically significant ( $t$-test: $t=2.3$ to $13.9, p<0.05$ to 0.001 ) for all the characteristics measured (Table 1). However, the Storer's index of sexual dimorphism was not high. It was more pronounced for the mass of skull (SM), minimum breadth between orbits (EntB) and for neurocranium length $(\mathrm{NeL})$. The least difference 
Table 1. Some linear skull parameters (cm) and skull mass (SM, g) of wolves from Latvia. Sample size $(n)$, average value of character $(\bar{x})$, standard deviation (SD), minimum and maximum values of measurements, coefficient of variation (CV), and Storer's index of sexual dimorphism are displayed. Statistical difference between males and females is given $\left(t\right.$-test: $\left.{ }^{*} p<0.05,{ }^{* *} p<0.001\right), n$ varies for different parameters because not all the measurements were available for every skull checked.

\begin{tabular}{|c|c|c|c|c|c|c|c|c|c|c|c|c|c|}
\hline \multirow{2}{*}{ Parameter } & \multicolumn{6}{|c|}{ Males } & \multicolumn{6}{|c|}{ Females } & \multirow{2}{*}{$\begin{array}{l}\text { Stcrer's } \\
\text { irdex }\end{array}$} \\
\hline & $n$ & $\bar{x}$ & Min & Max & SD & $\mathrm{CV}$ & $n$ & $\bar{x}$ & Min & Max & SD & $\mathrm{CV}$ & \\
\hline $\mathrm{CbL}^{* *}$ & 106 & 23.7 & 20.8 & 25.9 & 0.1 & 4.22 & 66 & 22.5 & 20.0 & 24.4 & 0.08 & 3.69 & 5.5 \\
\hline ToL** & 115 & 26.5 & 23.0 & 28.8 & 0.11 & 4.15 & 71 & 24.8 & 22.2 & 26.5 & 0.09 & 3.78 & 6.4 \\
\hline $\mathrm{BaL}^{* *}$ & 107 & 22.3 & 19.0 & 24.9 & 0.1 & 4.29 & 62 & 21.0 & 18.1 & 22.6 & 0.08 & 3.95 & 6.1 \\
\hline $\mathrm{FaL}^{* *}$ & 114 & 15.7 & 11.1 & 19.0 & 0.12 & 7.37 & 69 & 15.0 & 12.8 & 17.8 & 0.1 & 7.68 & 4.3 \\
\hline $\mathrm{NeL}^{* *}$ & 104 & 8.0 & 5.1 & 10.3 & 0.11 & 13.59 & 66 & 7.3 & 5.7 & 9.6 & 0.1 & 14.60 & 9.0 \\
\hline $\mathrm{NaL}^{* *}$ & 115 & 8.5 & 6.5 & 9.6 & 0.06 & 7.12 & 71 & 8.0 & 6.7 & 9.1 & 0.05 & 6.69 & 6.7 \\
\hline $\mathrm{MNaL}^{* *}$ & 115 & 9.7 & 7.4 & 11.4 & 0.06 & 6.60 & 72 & 9.1 & 7.6 & 10.1 & 0.06 & 6.02 & 6.5 \\
\hline $\mathrm{PaL}^{* *}$ & 111 & 12.0 & 10.2 & 18.8 & 0.08 & 6.98 & 66 & 11.2 & 9.7 & 12.4 & 0.06 & 5.34 & 6.6 \\
\hline $\mathrm{IPaL}^{* *}$ & 106 & 4.5 & 3.4 & 6.0 & 0.04 & 9.22 & 66 & 4.3 & 3.0 & 5.6 & 0.04 & 9.56 & 4.4 \\
\hline $\mathrm{C}^{1} \mathrm{~B}^{* *}$ & 114 & 4.7 & 3.1 & 5.3 & 0.04 & 7.54 & 72 & 4.3 & 3.1 & 4.8 & 0.04 & 8.21 & 8.5 \\
\hline $\mathrm{ZyB}^{* *}$ & 113 & 14.3 & 11.8 & 16.1 & 0.08 & 5.79 & 70 & 13.2 & 11.1 & 14.7 & 0.06 & 4.56 & 8.1 \\
\hline EntB $^{* *}$ & 114 & 4.7 & 3.7 & 6.0 & 0.05 & 9.84 & 72 & 4.3 & 3.1 & 5.1 & 0.04 & 9.10 & 9.4 \\
\hline LB $^{* *}$ & 114 & 4.2 & 3.1 & 5.5 & 0.04 & 9.32 & 71 & 4.0 & 3.0 & 5.0 & 0.04 & 9.50 & 4.2 \\
\hline $\mathrm{MB}^{* *}$ & 105 & 7.9 & 5.6 & 9.2 & 0.1 & 13.13 & 67 & 7.3 & 5.7 & 8.9 & 0.09 & 12.18 & 8.4 \\
\hline $\mathrm{SH}^{* *}$ & 112 & 8.8 & 7.5 & 10.4 & 0.07 & 7.53 & 69 & 8.3 & 7.1 & 9.6 & 0.05 & 6.47 & 6.4 \\
\hline $\mathrm{MdL}^{* *}$ & 113 & 18.9 & 11.9 & 20.8 & 0.1 & 5.31 & 70 & 17.8 & 15.7 & 19.9 & 0.07 & 4.12 & 5.7 \\
\hline TRL $^{\prime * *}$ & 115 & 8.5 & 7.3 & 10.7 & 0.05 & 5.79 & 71 & 8.2 & 6.8 & 9.7 & 0.05 & 5.58 & 4.3 \\
\hline $\mathrm{C}_{1} \mathrm{Br}^{*}$ & 100 & 1.5 & 0.9 & 1.9 & 0.02 & 15.83 & 68 & 1.4 & 0.9 & 1.9 & 0.02 & 15.41 & 4.9 \\
\hline $\mathrm{SM}^{* *}$ & 97 & 565.3 & 381 & 749 & 79.2 & 14.01 & 63 & 459.6 & 301 & 600 & 60.2 & 13.09 & 20.6 \\
\hline
\end{tabular}

between males and females was found for $\mathrm{C}_{1} \mathrm{Br}$ but nevertheless it was statistisally significant $(t=2.3, p<0.05)$.

The SM, NeL, MB and $\mathrm{C}^{1} \mathrm{~B}$ parameters had the highest coefficients of variaion. Males generally displayed slightly higher coefficients of variation than females. Coefficient of variation was higher in females only for the following parameers: FaL, NeL, IPaL, $\mathrm{C}^{1} \mathrm{~B}$, and LB (Table 1).

Since the wolf range in Latvia is relatively continuous, significant geograplical differences might not have been expected. However, the biggest trophies, evaluated by totaling $\mathrm{CbL}$ and $\mathrm{ZyB}$, originated mainly from northern and eastern Latvia Fig. 2). Comparison of the cranial parameters of wolves from the Kurland Peninsula, a relatively isolated population, and of wolves from northern and eastern Litvia revealed that most of the measurements were significantly bigger in wolves rom northern and eastern Latvia, both in males and females (Table 2). For exanple, ToL in males from Kurland was $26.1 \mathrm{~cm}$, that of males from the rest of the country $-26.6 \mathrm{~cm}(t=3.5, p<0.001)$. The only parameters that where significantly bigger 


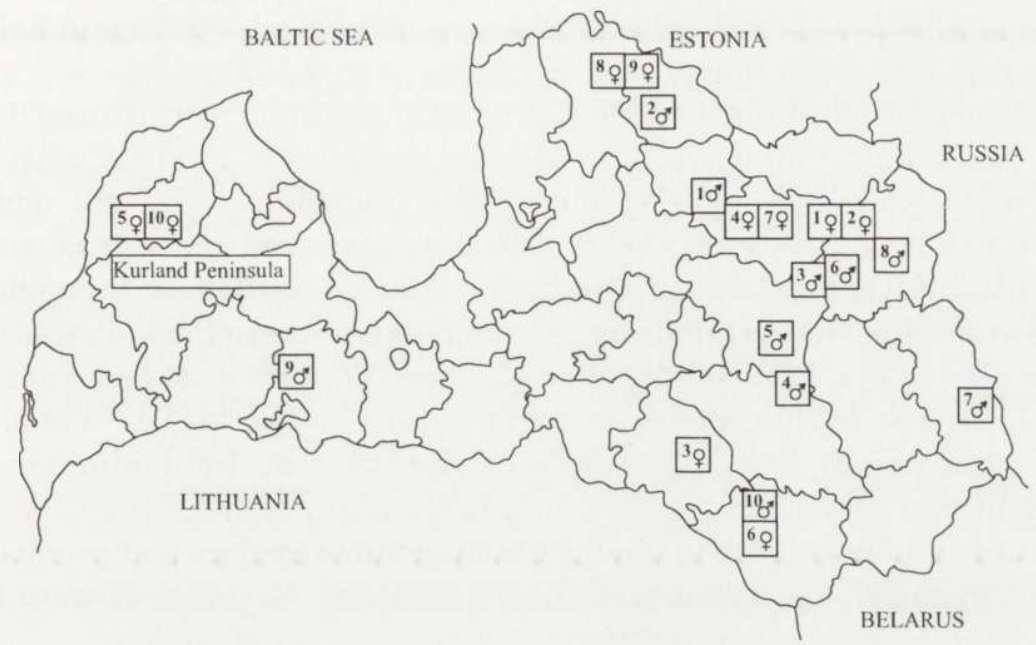

Fig. 2. Geographical distribution of 10 largest male and 10 largest female skulls in Latvia. Both males and females are ranked from 1 to 10 on the basis of the arithmetical sum of condylobasal length and zygomatic breadth. Solid lines are the borders of forestry districts.

Table 2. Differences in cranial parameters between wolves from western and northeastern Latvia. Statistical geographical difference in regard to sex is shown ( $t$-test: $\left.{ }^{*} p<0.05,{ }^{* *} p<0.001\right)$. Asterisk corresponds to the region where the given measurement was significantly larger.

\begin{tabular}{|c|c|c|c|c|c|c|}
\hline \multirow{2}{*}{$\begin{array}{l}\text { Parameter } \\
(\mathrm{cm})\end{array}$} & \multicolumn{3}{|c|}{ Western Latvia } & \multicolumn{3}{|c|}{ Northeastern Latvia } \\
\hline & Males & Females & Storer's index & Males & Females & Storer's index \\
\hline $\mathrm{CbL}$ & 23.66 & 22.32 & 6.0 & 23.76 & 22.48 & 5.5 \\
\hline ToL & 26.11 & 24.62 & 5.9 & $26.63^{* *}$ & 24.79 & 7.2 \\
\hline $\mathrm{BaL}$ & 21.93 & 20.73 & 5.6 & $22.38^{* *}$ & $21.04^{* *}$ & 6.2 \\
\hline $\mathrm{FaL}$ & $16.28^{* *}$ & $15.63^{* *}$ & 4.1 & 15.29 & 14.63 & 4.4 \\
\hline $\mathrm{NeL}$ & 7.14 & 6.46 & 10.0 & $8.49^{* *}$ & $7.8^{* *}$ & 8.5 \\
\hline $\mathrm{NaL}$ & 8.40 & 7.90 & 6.1 & 8.59 & 8.02 & 6.9 \\
\hline $\mathrm{MNaL}$ & 9.57 & 8.99 & 6.3 & $9.77^{*}$ & $9.15^{*}$ & 6.6 \\
\hline $\mathrm{PaL}$ & 11.89 & 11.12 & 6.7 & 12.04 & $11.29^{*}$ & 6.4 \\
\hline IPaL & 4.47 & $4.36^{* *}$ & 2.5 & 4.45 & 4.21 & 5.5 \\
\hline $\mathrm{C}^{1} \mathrm{~B}$ & 4.36 & 4.02 & 8.1 & $4.78^{* *}$ & $4.41^{* *}$ & 8.1 \\
\hline $\mathrm{ZyB}$ & 13.81 & 12.87 & 7.0 & $14.50^{* *}$ & $13.30^{* *}$ & 8.6 \\
\hline EntB & 4.43 & 4.08 & 8.2 & $4.80^{* *}$ & $4.35^{* *}$ & 9.8 \\
\hline LB & 3.88 & 3.77 & 2.9 & $4.28^{* *}$ & $4.10^{* *}$ & 4.3 \\
\hline MB & 6.76 & 6.69 & 1.0 & $8.43^{* *}$ & $7.58^{* *}$ & 10.6 \\
\hline $\mathrm{SH}$ & 8.31 & 7.77 & 6.7 & $9.07^{* *}$ & $8.52^{* *}$ & 6.3 \\
\hline MdL & 18.68 & 17.68 & 5.5 & $18.98^{* *}$ & 17.88 & 6.0 \\
\hline TRL $^{1}$ & 8.26 & 8.03 & 2.8 & $8.67^{* *}$ & $8.25^{* *}$ & 5.0 \\
\hline $\mathrm{C}_{1} \mathrm{Br}$ & 1.27 & 1.25 & 1.6 & $1.53^{* *}$ & $1.46^{* *}$ & 4.7 \\
\hline SM (g) & 565.37 & - & - & 565.22 & 458.08 & 20.9 \\
\hline
\end{tabular}


in the Kurland Peninsula were IPaL in females $(t=3.8, p<0.05)$ and FaL both in females and males $(t=5.9$ and 5.2 accordingly, $p<0.001)$.

Anomalous tooth formula were found in 18 skulls, which constituted $9.6 \%$ of all the skulls checked. Deviations from the normal tooth pattern were equally frequent in males and females. Congenital anomalies (oligodonty and polydonty) predominated $(77.8 \%$ of all anomalies). Polydonty occurred more frequently than oligodonty (5.3\% versus $2.1 \%$ of all skulls). The proportion of individuals with inherited or developmentally determined anomalies in tooth formula was higher in males than in females, both for oligodonty and polydonty $(t=24$ and 4 accordingly, $p<0.001)$. All cases of oligodonty derived from the lack of $\mathrm{M}_{3}(2.1 \%$ of all skulls $)$. Twice $\mathrm{M}_{3}$ was absent from both sides of the jaw, the total number of teeth equaling 40 .

In most cases of polydonty (53.3\%) additional minor molars and premolars were found both in upper and lower jaw. $\mathrm{M}^{3}(n=1)$ and $\mathrm{M}_{4}(n=2)$ were found as

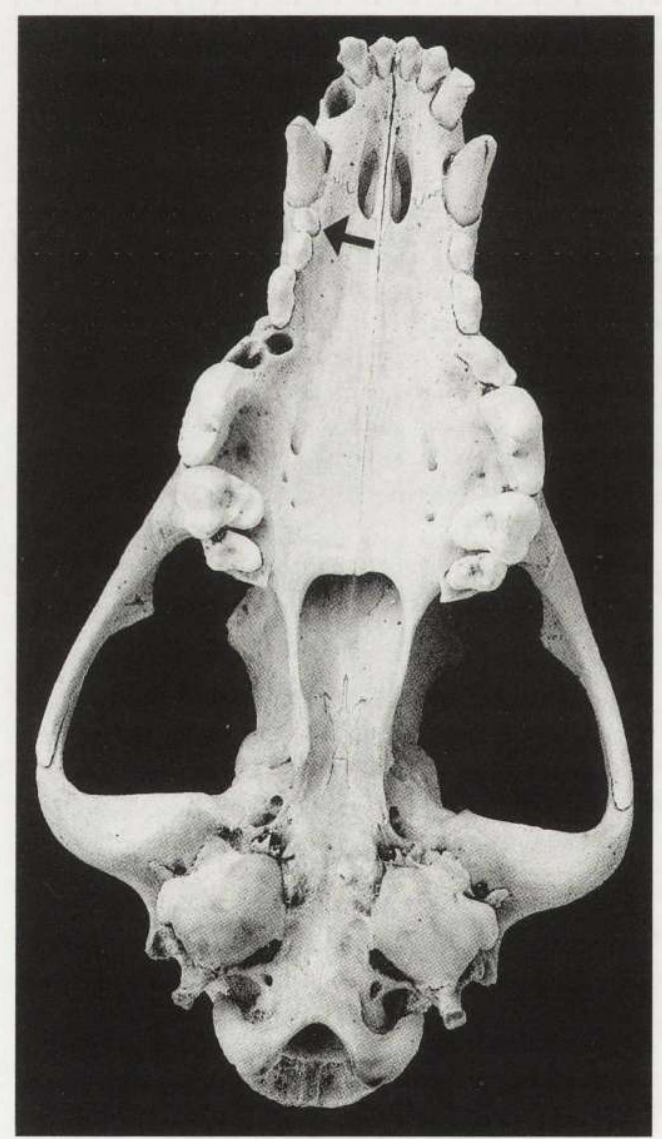

Fig. 3. Additional upper premolar $\left(\mathrm{P}^{1}\right)$ in a wolf skull from Latvia.

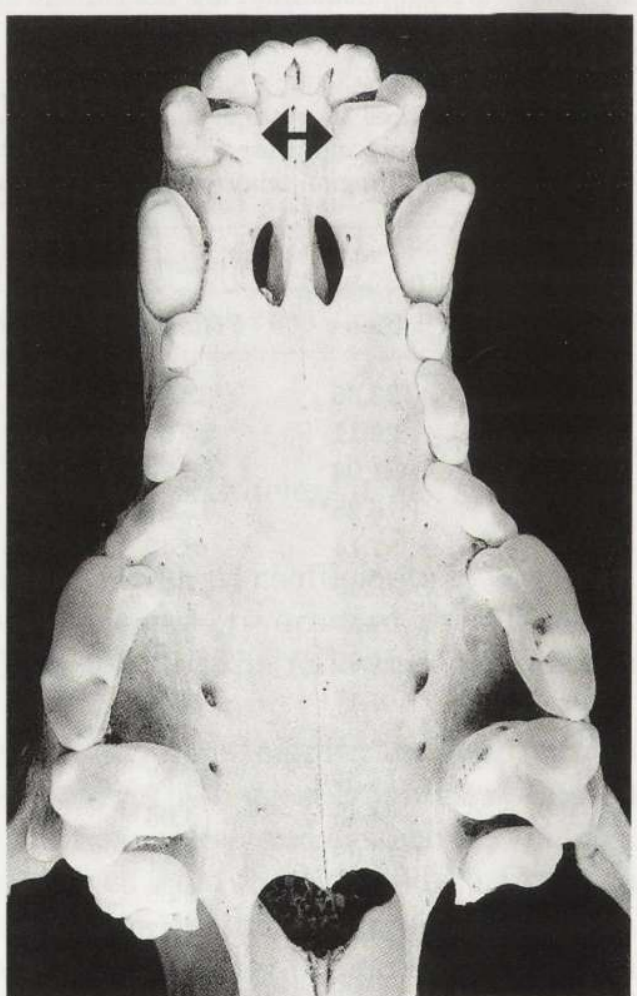

Fig. 4. Symmetric additional upper incsors in the female wolf from the Kurland Peninstla, Latvia. 
additional molars. All the additional premolars were situated at $\mathrm{P}^{1}(n=3)$ or $\mathrm{P}_{1}(n$ $=2$ ) (Fig. 3). Usually additional molars and premolars were of irregular shape and smaller than the corresponding premolars. Twice additional incisors were found. One skull had a double $\mathrm{I}_{1}$ just next to a canine. In another skull two additional symmetrical incisors $\left(\mathrm{I}^{2} \mathrm{I}^{2}\right)$ of normal shape were found in the second tooth row (Fig. 4).

Also, traumatic anomalies were found in the wolf skulls checked. In two, broken teeth were found (a canine and two incisors); once $\mathrm{P}_{1}$ and $\mathrm{P}^{3}$ were lacking but their absence was obviously secondary. Alveoli were filled up with bone but still visible.

\section{Discussion}

Results of this study revealed the great similarity between the Latvian wolf population and the neighbouring populations of the species. For example, mean $\mathrm{CbL}$ in males from Latvia was $23.7 \mathrm{~cm}$, in the Belarussian part of the Białowieża Forest it was the same, and in the Polish part it was $23.8 \mathrm{~cm}$. Zygomatic breadth of males from Latvia was bigger than that of wolves from Białowieża Forest: $14.3 \mathrm{~cm}$ versus 14.1 (Polish part) and $13.9 \mathrm{~cm}$ (Belarussian part) (Geptner et al. 1967, Okarma and Buchalczyk 1993). However, condylobasal length of females from Latvia was smaller than that from the Białowieża population: $22.5 \mathrm{~cm}$ vs 22.9 and $22.7 \mathrm{~cm}$ accordingly (Geptner et al. 1967, Okarma and Buchalczyk 1993). Zygomatic breadth of females from Latvia was $13.2 \mathrm{~cm}$ vs $13.5 \mathrm{~cm}$ in females from the Polish part of the Białowieża Forest (Okarma and Buchalczyk 1993). Comparison of some selected skull indices of the Latvian wolves with those from the Białowieża population showed that skull proportions were fairly similar (Table 3).

Condylobasal length of the studied skulls varied from 20.0 to $25.9 \mathrm{~cm}$, which exceeded the range 22.0 to $25.0 \mathrm{~cm}$ indicated previously for the wolves from Latvia by Tauriņš (1982). However, mean condylobasal length of $23.7 \mathrm{~cm}$ (males) and 22.5 $\mathrm{cm}$ (females) does not exceed the lower limit previously noted by Rossolimo and Dolgov (1965) for the forested zone of the former USSR.

Coefficients of variation of cranial parameters were generally higher in males with the exception for five characteristics (Table 1). The lowest variation was

Table 3. Comparison of some skull indices (\%) of wolf skulls from Białowieża Forest and Latvia. ${ }^{1}$ Polish part; Okarma and Buchalczyk 1993, ${ }^{2}$ Belarussian part; Geptner et al. 1967.

\begin{tabular}{|c|c|c|c|c|c|c|c|}
\hline \multicolumn{4}{|c|}{ Males } & \multicolumn{4}{|c|}{ Females } \\
\hline Index & Białowieża $^{1}$ & Białowieża $^{2}$ & Latvia & Index & Białowieża $^{1}$ & Białowieża $^{2}$ & Latvia \\
\hline EntB/CbL & 19.7 & 19.4 & 19.7 & $\mathrm{Zyb} / \mathrm{CbL}$ & 54.6 & 58.1 & 58.6 \\
\hline $\mathrm{LB} / \mathrm{CbL}$ & 17.7 & 17.9 & 17.5 & $\mathrm{MdL} / \mathrm{CbL}$ & 78.8 & - & 79.4 \\
\hline LB/EntB & 89.9 & 92.4 & 88.5 & ZyB/MdL & 74.8 & - & 73.8 \\
\hline
\end{tabular}


observed in ToL and CbL. Okarma and Buchalczyk (1993) obtained similar results from the Polish population.

Sexual dimorphism was statistically significant for all 19 parameters (Table 1). Skulls of females were smaller than those of males, similarly to the Polish population (Okarma and Buchalczyk 1993) and those from different regions of the former USSR (Geptner et al. 1967). The difference was the least pronounced in $\mathrm{C}_{1} \mathrm{Br}: 1.5 \mathrm{~cm}$ in males and $1.4 \mathrm{~cm}$ in females $(t=2.3, p<0.05)$.

A pronounced difference between the two parts of the Latvian wolf population from the Kurland Peninsula and the rest of the country - was found. Eleven parameters were bigger in the northeastern population in both males and females, two in males only and one in females only (Table 2). This possibly indicates the impact of invaders from the neighbouring wolf populations in the north and the east. Although there are no geographical barriers between the two subpopulations, wolves of the Kurland Peninsula are separated from the eastern source population by the regions with low wolf density like deforested Zemgale lowland in the south of the country. Therefore, some divergence can not be excluded. Moreover, the difference can be heightened by more intensive hunting in Kurland, resulting in a lower average age of the animals there. It has been often reported in national press that hunters of Kurland have carried out wide wolf control measures while in eastern regions wolves are less intensively persecuted and are killed mostly by accident. Interestingly, facial length was significantly bigger in wolves from the Kurland Peninsula both in males and females. Another parameter - length of incisura palatina - was also significantly bigger in Kurland but in females only (Table 2).

Tooth formula in the Latvian wolf population is relatively conservative anomalies occurred only in $9.6 \%$. All deviations in tooth pattern belong to the second group of variations according to Wolsan (1984b) as the tooth set in wolves is rigid having no extreme variants as it is observed, for instance, in weasels (Wolsan 1983). In Ukraine, oligodonty and polydonty was found in $16.2 \%$ of skulls (Lihotop 1994). In wolves from the Western Carpathians, variations of dentition happened in $27.7 \%$ of animals (Hell and Duricka 1989) while in the Far East of Russia deviations from the normal tooth formula were found from 21.3 to $38.3 \%$ of the population (Yudin 1989). Such a high proportion of irregular tooth number was partly due to traumatic changes in tooth formula, though, natural causes played the main role (Yudin 1989). Congenital deviations in the teeth number may have two different causes - from an additional tooth germ and as a result of splitting of one germ due to a mutation or other factors affecting genetic control (Wolsan 1984c). Only the second type can be called true anomalies (Wolsan 1984b). In this case additional teeth are similar to the adjacent ones, which is corresponding to most of the deviations described from Latvia.

Traumatic deviations in the tooth formula of Latvian wolves also were rare ( $2.1 \%$ of all the skulls). Possibly, this is due to the fact that the animals with serious injuries are those most likely to be eliminated. 
In Poland, the percentage of oligodonty and polydonty was similar to that in Latvia - 10.7\% (Buchalczyk et al. 1981). The proportion of polydonty in the population was higher than that of oligodonty in the Carpathians and Poland (Buchalczyk et al. 1981, Hell and Duricka 1989) and lower in Ukraine and the Far East of Russia (Yudin 1989, Lihotop 1994). In different regions, certain types of dental anomalies are similar, eg oligodonty on $\mathrm{M}_{3}$, polydonty on premolars (Buchalczyk et al. 1981, Hell and Duricka 1989, Yudin 1989, Lihotop 1994).

Congenital tooth anomalies (oligodonty and polydonty) were more often found in males, although the difference was not statistically significant. The same trend has been described from Poland (Buchalczyk et al. 1981) and Ukraine (Lihotop 1994).

Premolars and minor molars are less functional than other teeth and therefore they are subject to active evolutionary transformations resulting in deviations in teeth number (Yudin 1989). However, incisors also often show variation (Wolsan 1984a). Interestingly, the anomaly with two additional symmetrical incisors has also been described from Poland (Buchalczyk et al. 1981).

Thus, the similarity between the close populations of Latvia and Poland supports the idea expressed in previous studies that dental deviations might be used in phylogenetic studies and in studies on the population structure of the species (Buchalczyk et al. 1981, Hell and Duricka 1989, Yudin 1989). Further studies from the other Baltic States (Estonia and Lithuania) and the neighbouring territories in Russia and Belarus would add more information and would make a thorough comparative analysis possible.

Acknowledgements: We thank A. Strazds, M. Rantinš, E. Doniks, J. Baumanis, J. Taurinš for their help in data collection. We are very grateful to Dr H. Okarma and three anonymous reviewers for their invaluable help while reviewing and commenting on the paper. We express our cordial appreciation to $\mathrm{N}$. Benvie for reviewing the English of the manuscript.

\section{References}

Ansorge H. 1994. Intrapopular skull variability in the red fox, Vulpes vulpes (Mammalia, Carnivora, Canidae). Zoologische Abhandlungen Staatliches Museum für Tierkunde Dresden 48(6): 103-123.

Ansorge H. and Meinig H. 1996. Craniological data and age structure of red foxes (Vulpes vulpes arabica Thomas, 1902) from Oman. Mammalia 12: 13-19.

Bibikov D. I. (ed) 1985. [The wolf. History, systematics, morphology, ecology]. Nauka Publishers, Moskva: 1-606. [In Russian]

Buchalczyk T., Dynowski J. and Szteyn S. 1981. Variations in number of teeth and asymmetry of the skull in the wolf. Acta Theriologica 26: 23-30.

Geptner V. G., Naumov N. P., Yurgenson P. B., Sludskii A. A., Chirkova A. F. and Bannikov A. G. 1967. [Mammals of the USSR]. Vol. 2. Vysshaja shkola Publishers, Moskva: 1-1004. [In Russian]

Görner M. and Hackethal H. 1987. Säugetiere Europas. Radebeul: Neumann Verlag, Leipzig: 1-372.

Hell P. and Duricka J. 1989. Anomalies of the dentition of the West Carpathian wolf (Canis lupus). Folia Venatoria 19: 339-347. [In Slovak with English summary]

Kalninš A. 1943. [Huntsmanship]. Latvju Grāmata, Riga: 1-704. [In Latvian]

Liepa I. 1974. [Biometry]. Zvaigzne, Riga: 1-336. [In Latvian] 
Lihotop R. I. 1994. Cranial and dentition anomalies in wolf of the Ukranian territory. Vestnik Zoologii 3: 45-50. [In Russian with English summary]

Novikov G. A. 1956. [Carnivorous mammals of the USSR fauna]. AN SSSR Publishers, Moskva Leningrad: 1-293. [In Russian]

Okarma H. and Buchalczyk T. 1993. Craniometrical characteristics of wolves Canis lupus from Poland. Acta Theriologica 38: 253-262.

Rossolimo O. L. and Dolgov V. A. 1965. Variability of the skull in Canis lupus Linnaeus, 1758 from the USSR. Acta Theriologica 10: 195-207. [In Russian with English summary]

Sokal R. R. and Rohlf F. J. 1981. Biometry. W. H. Freeman and Co., New York: 1-859.

Tauriňš E. 1982. [Latvian mammals]. Zvaigzne, Riga: 1-256. [In Latvian]

Yudin V. G. 1989. The dental system of Canis lupus (Carnivora, Canidae) from the far east of the USSR. Zoologicheskii Zhurnal 68(8): 115-123. [In Russian with English summary]

Wolsan M. 1983. Ancestral characters in the dentition of the weasel Mustela nivalis L. (Carnivora, Mustelidae). Annales Zoologici Fennici 20: 47-51.

Wolsan M. 1984a. Concerning the variation in the number, shape and size of incisors in fissiped carnivores. Acta Zoologica Cracoviensia 27: 107-120.

Wolsan M. 1984b. Two dental anomalies in the weasel (Mustela nivalis L.): a supernumerary premolar and reduced upper molar (Mammalia, Carnivora, Mustelidae). Zoologische Abhandlungen 40(5): $67-70$.

Wolsan M. 1984c. The origin of extra teeth in mammals. Acta Theriologica 29: 128-133.

Received 13 October 1999, accepted 12 January 2000. 